\title{
Quantifying Changes in Nuclear Organization in Normal vs. Cancer Cells using X- ray Tomography
}

\author{
Elizabeth A. Smith ${ }^{1}$, Mark A. Le Gros, ${ }^{1,2}$ Markko Myllys ${ }^{3}$, and Carolyn A. Larabell ${ }^{1,2}$ \\ ${ }^{1 .}$ Department of Anatomy, University of California San Francisco, San Francisco USA. \\ 2. Physical Biosciences Division, Lawrence Berkeley National Laboratory, Berkeley USA. \\ ${ }^{3 .}$ Department of Physics, University of Jyväskylä, Jyväskylä FI.
}

Soft X-ray tomography (SXT) is similar in concept to the well-established medical diagnostic technique, computed axial tomography (CAT), except SXT is capable of imaging with a spatial resolution of 50 $\mathrm{nm}$, or better. With SXT we can examine whole, hydrated cells (between 10-15 $\mu \mathrm{m}$ thick), eliminating the need for time-consuming embedding and sectioning procedures. For SXT, cells are imaged using Xray energies between the $\mathrm{K}$ shell absorption edges of carbon $(284 \mathrm{eV}, \lambda=4.4 \mathrm{~nm})$ and oxygen $(543 \mathrm{eV}$, $\lambda=2.3 \mathrm{~nm}$ ). In this energy range, photons readily penetrate the aqueous environment while encountering significant absorption from carbon- and nitrogen-containing organic material. Consequently organic material absorbs approximately an order of magnitude more strongly than water, producing a quantifiable natural contrast image of cellular structures[1]. SXT, like other tomography modalities, requires recording images from multiple different viewing angles. By collecting images from multiple angles through 360 degrees of rotation, SXT reconstructions yield information at isotropic resolution.

Images are formed using unique optics called zone plates (ZP). An X-ray ZP optic consists of a number of concentric nanostructured metal rings, or zones, formed on a thin X-ray transmissive silicon nitride membrane. The width of the outermost ring determines the spatial resolution of the ZP lens, whereas the thickness of the rings determines the focusing efficiency. In the microscope we utilize, the condenser ZP lens has an overall diameter of $1 \mathrm{~cm}, 41,667$ zones made with approximately $200 \mathrm{~nm}$ thick nickel, and a $5 \mathrm{~mm}$ central stop. The high-resolution objective ZP lens has a diameter of $63 \mu \mathrm{m}$ and an outer zone width of $50 \mathrm{~nm}$ to assure the entire cell is in focus.

Because SXT is fast ( 5 min per tomographic data set), we can examine large numbers of cells. Since organic material absorbs approximately an order of magnitude more strongly than water, the highcontrast image of cellular structures is quantifiable. X-ray absorption follows Beer's Law, therefore the absorption of photons is linear and a function of the biochemical composition at each point in the cell. As a result, a linear absorption coefficient (LAC) value of each voxel can be calculated. For example, lipid drops with high concentrations of carbon are more highly absorbing ( $\mathrm{LAC}=0.7 \mu \mathrm{m}^{-1}$ ) than fluidfilled vesicles $\left(\mathrm{LAC}=0.2 \mu \mathrm{m}^{-1}\right)[2]$.

To determine the location of specific molecules with respect to cellular structures, we overlay molecular information obtained with fluorescence microscopy of a cell on the structural information obtained with $\mathrm{X}$-ray tomography of the same cell[3]. This makes it possible to localize molecules tagged with genetically encoded proteins (XFPs, etc.) without having to fix and permeabilize cells to allow metal particle entry into cells.

SXT can be used for a variety of cell biological studies, as demonstrated by recent publications that reveal its unique role in biological imaging. For example, SXT has been used to: 1) reveal sub-cellular consequences of treating $C$. albicans cells with antifungal peptoids[4]; 2) image $P$. falciparum-infected 
red blood cells[5]; 3) map the sexual and asexual stages of the parasite, $P$. falciparum, and measure changes in RBC hemoglobin concentration during parasite infection[6]; 4) quantitatively characterize haploid and diploid strains of $S$. cerevisiae during the cell cycle[7]; and 5) to elucidate the organization of olfactory receptor genes and shed light on a 20 -year-old mystery surrounding the monogenic and monoalllelic expression of these genes in the mouse olfactory epithelium[8].

More recently we demonstrated the ability of SXT to obtain novel quantitative information about nuclear organization and chromatin topology in normal cells obtained from mice. We examined parameters such as nuclear volume, heterochromatin concentration, and the 3-D spatial distribution of chromatin; we then measured the changes in these parameters during cell differentiation (manuscript submitted) and tumor formation. Studies of tumor cells reveal distinct changes of all nuclear measurements compared with normal cells; I will present these data and the statistical analyses of several different cell types.

\section{References}

[1] G McDermott, MA Le Gros, and CA Larabell, In "Annual Review of Physical Chemistry", eds. MA Johnson and TJ Martinez, 63 (2012), p. 225.

[2] G McDermott, MA Le Gros, CG Knoechel, M Uchida, and CA Larabell, Trends in Cell Biology 19(11) 2009, p. 587.

[3] BP Cinquin, M Do, G McDermott, AD Walters, M Myllys, EA Smith, O Cohen-Fix, MA LeGros, and CA Larabell, Journal of cellular biochemistry 115(2) 2013, p209.

[4] M Uchida, G McDermott, M Wetzler, MA Le Gros, M Myllys, C Knoechel, AE Barron, and CA Larabell, PNAS 106(46) 2009, p. 19375.

[5] E Hanssen E, C Knoechel, N Klonis, N Abu-Bakar, S Deed, M LeGros, C Larabell, and L Tilley, J Struct Biol 173(1) 2011, p. 161.

[6] E Hanssen, C Knoechel, M Dearnley, MW Dixon, M Le Gros, C Larabell, and L Tilley, J Struct Biol 177(2) 2012, p 224.

[7] M Uchida, Y Sun, G McDermott, C Knoechel, MA Le Gros, D Parkinson, DG Drubin, and CA Larabell, Yeast 28(3) 2011, p. 227.

[8] EJ Clowney, MA LeGros, CP Mosley, FG Clowney, EC Markenskoff-Papadimitriou, M Myllys, G Barnea, CA Larabell, and S Lomvardas, Cell 151(4) 2012, p. 724.

[9] The authors acknowledge funding from the National Institute of General Medical Science (award number P41GM63948) and the Epigenomics Roadmap Program (award number 5R01DA030320) of the National Institutes of Health; and the US Department of Energy, Office of Biological and Environmental Research (contract number DE-AC02-05CH11231). 